\title{
Induction of IL-6 and IL-8 Expression by Leptin Treatment in Periodontal Ligament Cells and Gingival Fibroblasts
}

\author{
Hong-Gyu Park, Ji-Hye Kim ${ }^{2}$, Jeong-Heon Cha ${ }^{1,2,3}$, Eun-Jung Bak ${ }^{3}$, and Yun-Jung Yoo ${ }^{1,2 *}$ \\ ${ }^{I}$ Oral Cancer Research Institute, Yonsei University College of Dentistry, Seoul, Korea \\ ${ }^{2}$ Department of Applied Life Science, The Graduate School, Yonsei University, Seoul, Korea \\ ${ }^{3}$ Department of Oral Biology, Yonsei University College of Dentistry, Seoul, Korea
}

(received March 28, 2013; revised April 24, 2013; accepted April 25, 2013)

Leptin is one of the adipocytokines produced from adipose tissue but its functions in periodontal tissue have not previously been investigated. In our current study, we examined the effects of leptin on the expression of interleukin (IL)-6 and IL-8 in periodontal ligament (PDL) cells and gingival fibroblasts. Leptin receptor expression was evaluated by RT-PCR and the production of cytokines was measured by ELISA. The phosphorylation of Akt and Erk1/2 was assessed by westem blotting. mRNA of long and short form leptin receptors were detected in both PDL cells and gingival fibroblasts. Leptin was found to increase the production of $I L-6$ and $I L-8$ in both of these cell types, an effect which was not blocked by polymyxin $B$, an inhibitor of lipopolysaccharide (LPS). Leptin did not alter the production of IL-6 and IL-8 induced by LPS in PDL cells but increased Akt and Erk1/2 phosphorylation in these cells. These results suggest that leptin acts as an inducer of IL-6 and IL-8 in PDL cells and gingival fibroblasts.

Key words: Periodontal ligament cells, Gingival fibroblasts, Leptin, Interleukin-6, Interleukin-8

\footnotetext{
*Correspondence to: Yun-Jung Yoo, Department of Oral Biology, Yonsei University College of Dentistry, 50 , Seodaemoon-gu, Seoul, 120-752, Korea. Tel: +82-2-2228-3060, Fax: +82-2-2227-7903, E-mail: yu618@yuhs.ac
}

This is an Open-Access article distributed under the terms of the Creative Commons Attribution Non-Commercial License(http://creativecommons.org/licenses/by-nc/3.0) which permits unrestricted noncommercial use, distribution, and reproduction in any medium, provided the original work is properly cited.

\section{Introduction}

Leptin is one of the adipokines produced from adipocytes [1]. Leptin is encoded by the gene obese (ob), and its circulating levels are correlated with white adipose tissue mass $[1,2]$. Leptin decreases food intake and increases energy consumption by inducing anorexigenic factors. Additionally, leptin behaves as a mediator of inflammation in monocytes/ macrophages and neutrophils [2]. Leptin stimulates proliferation, phagocytosis, and expression of cytokines and enzymes such as interleukin (IL)-1, IL-6, tumor necrosis factor (TNF), nitric oxide synthase, and cyclooxygenase- 2 in monocytes/ macrophages. Leptin also increases chemotaxis and hydrogen peroxide production in neutrophils. Leptin receptors are encoded by the gene diabetes $(d b)$, and multiple receptor isoforms result from alternative splicing of the $d b$ gene [1-4]. Among the isoforms, the long form of leptin receptor has a cytoplasmic domain with Janus kinase binding sites and plays a pivotal role mediating leptin signaling.

Periodontitis is an inflammatory disease caused by bacteria or an immune reaction against bacteria [5,6]. Previous studies have demonstrated the relationship between periodontitis and leptin levels. Leptin concentration decreases in gingival crevicular fluid (GCF), but increases in serum, depending on the severity of periodontal destruction [7-9]. Elevated serum leptin level in periodontitis is associated with acute myocardial infarction, suggesting that the inc- 
rease in serum leptin in patients with periodontitis accelerates the inflammatory process in arteriosclerotic lesions and increases the risk for acute myocardial infarction [10]. Although studies have suggested that the higher concentration of leptin in GCF may play a protective role in periodontal tissue, the mechanism underlying the change in leptin level or the function of leptin has not been investigated in periodontal tissue. The effect of leptin on periodontal ligament (PDL) cells and gingival fibroblasts has not been determined, but it was reported recently that leptin and the leptin receptor affect function of fibroblasts in synovium and dermis [11,12]. PDL cells and gingival fibroblasts mainly consist of periodontal tissue and play an important role producing pro-inflammatory cytokines in periodontal tissue [13]. IL-6 is closely related with the recruitment of $T$ cells and acts as a $\mathrm{T}$ and $\mathrm{B}$ cell differentiation factor [14]. IL-8 stimulates the expression of adhesion molecules (CD11/18), the migration, and the release of enzyme and reactive oxygen intermediates in neutrophils [15]. Therefore, to investigate the function of leptin in periodontal tissue, we assessed leptin receptor expression and the effect of leptin on expression of pro-inflammatory cytokines such as IL-6 and IL-8 in PDL cells and gingival fibroblasts.

\section{Material and Methods}

\section{Cell cultures}

PDL or gingival fibroblast cells were prepared from teeth extracted for orthodontic treatment or from gingival tissue. This protocol was approved by the Institutional Review Board of Yonsei Dental Hospital (IRB No. 2-2010-0005). PDL tissue fragments were removed from the middle one- third of the extracted tooth roots and were washed three times with $\alpha$-modified Eagle's medium ( $\alpha$-MEM; Gibco BRL, Rockville, MD, USA) containing $300 \mathrm{mg} / \mathrm{ml}$ streptomycin, $300 \mathrm{unit} / \mathrm{ml}$ penicillin, and $0.75 \mathrm{mg} / \mathrm{ml}$ amphotericin-B (Gibco $\mathrm{BRL})$. PDL tissue fragments were placed in $100 \mathrm{~mm}$ dishes containing $\alpha$-MEM supplemented with $100 \mathrm{mg} / \mathrm{ml}$ streptomycin, $100 \mathrm{unit} / \mathrm{ml}$ penicillin, $0.25 \mathrm{mg} / \mathrm{ml}$ amphotericin-B, and 20\% fetal bovine serum (FBS, Gibco BRL). The culture media were replaced every 2 days until cells grew from the fragments, and then the cultures were maintained with $\alpha$ -MEM containing antibiotics and 10\% FBS. Upon reaching $70 \%$ confluence, the cells were removed with $0.25 \%$ trypsin and passaged to $100 \mathrm{~mm}$ dishes. Gingival fibroblasts were prepared from gingival tissues excised for crown lengthening. Gingival tissues were cut into small fragments and then the tissue fragments were incubated in $2.4 \mathrm{U}$ dispase II (Roche, Mannheim, Germany) and $0.25 \%$ collagenase (Roche) for 1 $\mathrm{h}$ at $37^{\circ} \mathrm{C}$. The tissue fragments were then separated into epithelial and connective tissues. Connective tissue fragments were placed in $100 \mathrm{~mm}$ dishes containing Dulbecco's Modified Eagle's Medium (Gibco BRL) supplemented with antibiotics and $10 \%$ FBS and were cultured according to the same procedure as the PDL cells. THP-1 monocytes were maintained in Roswell Park Memorial Institute medium (Gibco BRL) 1640 containing antibiotics and 10\% FBS.

\section{Reverse transcription-polymerase chain reaction (RT-PCR)}

PDL cells or gingival fibroblasts $\left(5 \times 10^{5}\right.$ cells/well) were cultured in 6 well plates. THP- 1 monocytes $\left(5 \times 10^{5}\right.$ cells/ well) were plated in 6 well culture plates and treated with phorbol myristic acid (100 ng/ml, Sigma, St. Louis, USA) for $24 \mathrm{~h}$ to induce differentiation of monocytes into macrophages. Total RNA in adipose tissue from the inguinal region, PDL cells, gingival fibroblasts, or THP-1 macrophages was isolated with Trizol reagent (Invitrogen, Carlsbad, CA, USA). Two $\mu \mathrm{g}$ of total RNA was converted to cDNA using an RT Premix kit (Bioneer, Seoul, Korea) in accordance with the manufacturer's instructions. The cDNA population was amplified with i-StarTaq (Intron Biotech, Seongnam, Korea) and compared with the concurrently measured GAPDH expression level. For semi quantitative RT-PCR, two concentrations of the cDNA template were amplified to determine the optimal cDNA amounts. In addition, several PCR cycles were tested to determine the range in which amplification was in the exponential phase. The PCR products were then resolved by electrophoresis on $1 \%$ agarose gels containing ethidium bromide. The primers, annealing temperatures and the optimized PCR cycle number are given in Table $1[16,17]$.

\section{Measurement of IL-6 and IL-8 production by enzyme- linked immunosorbent assay (ELISA)}

PDL cells or gingival fibroblasts $\left(1.7 \times 10^{5}\right.$ cells/well $)$ were plated in 24 well culture plates and maintained in media containing antibiotics and 10\% FBS for $7 \mathrm{~h}$. After the indicated time, the cells were starved in serum-free media for $20 \mathrm{~h}$. Then, the cells were treated with human recombinant leptin (R\&D Systems, Minneapolis, MN, USA) or LPS (Sigma Chemical Co., St. Louis, Mo, USA) for $24 \mathrm{~h}$. The cells were pretreated with polymyxin B (Sigma) for $1 \mathrm{~h}$ 
Table 1. PCR primer sequences

\begin{tabular}{|c|c|c|c|c|}
\hline Gene & Primer sequence $\left(5^{\prime}-3^{\prime}\right)$ & Product length (bp) & Annealing Tm. $\left({ }^{\circ} \mathrm{C}\right)$ & Cycles \\
\hline Leptin & $\begin{array}{l}\text { F : TTCACACACGCAGTCAGTCTCC } \\
\text { R : ACAGAGTCCTGGATAAGGGGTG }\end{array}$ & 348 & 60 & 28 \\
\hline Leptin receptor Long form & $\begin{array}{l}\text { F : CAGAAGCCAGAAACGTTTGAG } \\
\text { R : AGCCCTTGTTCTTCACCAGT }\end{array}$ & 344 & 52 & 35 \\
\hline Short form 219.1 & $\begin{array}{l}\mathrm{F}: \text { TTGGAAGCCCCTGATGAAA } \\
\mathrm{R}: \text { AGCAGATAAACAAGTGAACAAAG }\end{array}$ & 822 & 52 & 35 \\
\hline Short form 219.2 & $\begin{array}{l}\text { F : TTGGAAGCCCCTGATGAAA } \\
\text { R : AGGTGCGCAGCGAGGTAGGA }\end{array}$ & 772 & 52 & 35 \\
\hline Short form 219.3 & $\begin{array}{l}\text { F : ATTCAATTGGTGCTTCTGTT } \\
\text { R : CATTGGGTTCATCTGTAGTG }\end{array}$ & 573 & 52 & 35 \\
\hline GAPDH & $\begin{array}{l}\mathrm{F}: \text { :CGGAGTCAACGGATTTGGTCGTAT } \\
\text { R: AGCCTTCTCCATGGTGGTGAAGAC }\end{array}$ & 307 & 56 & 28 \\
\hline
\end{tabular}

and then treated with leptin or LPS for $24 \mathrm{~h}$. The PDL cells were treated with LPS in the absence or presence of leptin for $24 \mathrm{~h}$ to estimate the effect of leptin on LPS-induced cytokine expression. After treatment, the level of IL- 6 or IL- 8 was measured in the culture supernatants from cells using a commercially available ELISA kit (BioLegend, San Diego, CA, USA) in accordance with the manufacturer's instructions.

\section{Cell viability assay}

Cell viability was measured using the 3-(4,5-dimethylthiazol-2-yl)2,5-diphenyl tetrazolium bromide (MTT) assay. PDL cells or gingival fibroblasts $\left(1.7 \times 10^{5}\right.$ cells/well $)$ were seeded in 24 well plates and maintained in media containing antibiotics and $10 \%$ FBS. After $7 \mathrm{~h}$, the cells were starved in serum-free media for $20 \mathrm{~h}$ and then treated with the indicated concentrations of polymyxin B for $24 \mathrm{~h}$. After treatment, $20 \mu$ of MTT solution ( $5 \mathrm{mg} / \mathrm{ml}$ in PBS, Sigma) was added to each well. After a $4 \mathrm{~h}$ incubation, the media were aspirated, and $200 \mu$ of dimethylsulfoxide (Sigma) was added to each well to dissolve the MTT-formazan crystals. The absorbance was measured with an MRX II microplate reader (Dynatech Labs, Chantilly, VA, USA) at $570 \mathrm{~nm}$.

\section{Westem blotting}

PDL cells $\left(5 \times 10^{5}\right.$ cells $/$ well $)$ were cultured in 6 well plates and maintained in media containing antibiotics and $10 \%$ FBS for the protein analysis. After $7 \mathrm{~h}$, the cells were starved in serum-free media for $20 \mathrm{~h}$ and then treated with $10 \mu \mathrm{g} / \mathrm{ml}$ leptin for the indicated time intervals. Then whole cells were lysed in $1 \times$ lysis buffer $[20 \mathrm{mM}$ Tris- $\mathrm{HCl}(\mathrm{pH}$ 7.5), $150 \mathrm{mM} \mathrm{NaCl}, 1 \mathrm{mM} \mathrm{Na} \mathrm{F}_{2}$ EDA, $1 \%$ Triton, $2.5 \mathrm{mM}$ sodium pyrophosphate, $1 \mathrm{mM} \beta$-glycerophosphate, $1 \mathrm{mM}$
$\mathrm{Na}_{3} \mathrm{VO}_{4}, 1 \mu \mathrm{g} / \mathrm{ml}$ leupeptin, and $1 \mathrm{mM}$ PMSF; Cell Signaling Technology, Danvers, MA, USA]. After centrifugation, the supernatant was used for the protein assay. Protein concentrations were determined with the BSA Protein Assay kit (Bio-Rad, Hercules, CA, USA). Forty $\mu \mathrm{g}$ of protein was electrophoresed on $10 \%$ SDS-polyacrylamide gel. The electrophoretically separated proteins were electroblotted onto PVDF membranes (Bio-Rad). The membranes were blocked with $5 \%$ BSA in Tris buffer saline $(10 \mathrm{mM}$ Tris- $\mathrm{HCl}, 166 \mathrm{mM} \mathrm{NaCl}, \mathrm{pH}$ 7.4). The primary antibodies were anti-phospho-Akt (Cell Signaling Technology), antiphospho-Erk1/2 (Cell Signaling Technology), anti-Akt (Cell Signaling Technology), or anti-Erk1/2 (Cell Signaling Technology) and were diluted at 1:1000, respectively. Peroxidase-conjugated anti-rabbit antibody (Jackson Immuno Research, West Grove, PA, USA) was used at 1:2500 as the secondary antibody. Protein bands were visualized with an ECL kit (Amersham Bioscience, Buckinghamshire, UK). Band intensity was measured using Spot Denso Analysis of FROG 2000 software (Alpha Innotech, San Leandro, CA, USA).

\section{Statistical analysis}

Results were analyzed using one-way analysis of variance and Tukey's test (SPSS Inc., Chicago, IL, USA). A p value $<0.05$ was considered significant.

\section{Results}

\section{Expression of leptin and leptin receptors}

To observe the expression of leptin and leptin receptors in periodontal tissue, the expression in PDL cells and gingival fibroblasts was estimated by RT-PCR. Leptin was expressed 
A.

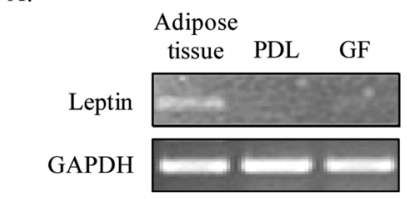

B.

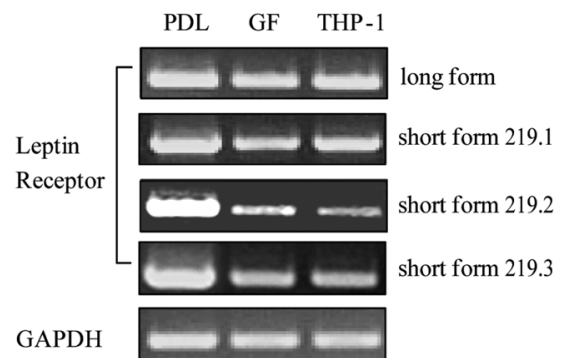

Fig. 1. Expression of leptin and leptin receptors in periodontal ligament (PDL) cells and gingival fibroblasts. Expression of leptin was assessed by RT-PCR in adipose tissue, PDL cells, and gingival fibroblasts (GF) (A). Expression of leptin receptors was estimated by RT-PCR in PDL cells, GF, and THP-1 macrophages (B).

in adipose tissues isolated from subcutaneous tissue in the inguinal region, but was not expressed in PDL cells or gingival fibroblasts (Fig. 1A). Long and short forms of the leptin receptor were expressed in PDL cells, gingival fibroblasts, and THP-1 macrophages (Fig. 1B). In leptin receptors of gingival fibroblasts and THP-1 macrophages, expression level of short form 219.2 was lower than that of PDL cells and other short forms (291.1 and 291.3).

\section{Effect of leptin on IL-6 and IL-8 expression}

To observe whether leptin acts as an inducer of cytokines in periodontal tissue, IL-6 and IL-8 protein levels in culture supernatants of PDL cells and gingival fibroblasts treated with leptin were estimated by ELISA. Leptin treatment increased IL-6 and IL-8 expression in PDL cells (Fig. 2A and $2 \mathrm{~B}$ white bar). When compared to those of untreated PDL cells, IL-6 expression significantly increased at a concentration of $10 \mu \mathrm{g} / \mathrm{ml}$ leptin (Fig. 2A white bar). IL-8 expression increased in a dose dependent manner (Fig. 2B whitebar). The expression of IL-6 and IL-8 in gingival fibroblasts was also induced similar to that in PDL cells (Fig. 2A and $2 \mathrm{~B}$ black bar). That is, IL- 6 expression increased significantly in a dose-dependent manner and IL-8 expression was significantly elevated at a concentration of $10 \mu$ $\mathrm{g} / \mathrm{ml}$ as compared to untreated cells.

To confirm the effect of leptin on cytokine expression,
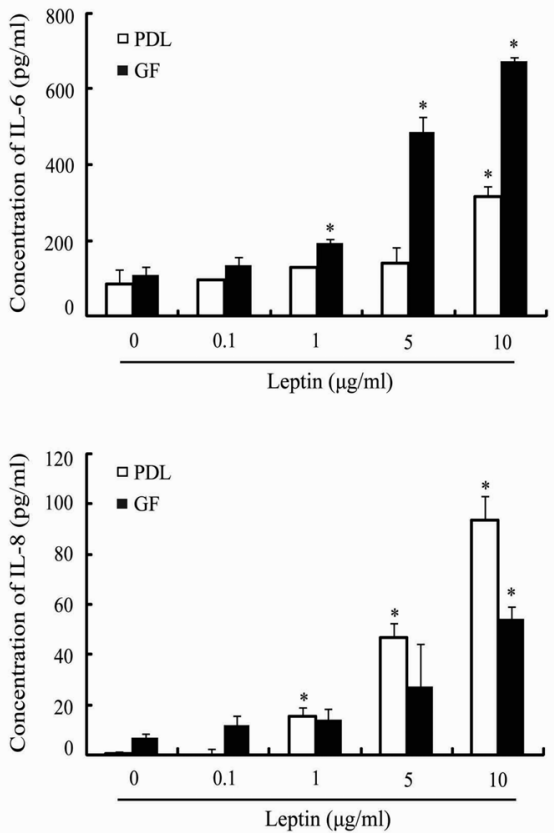

Fig. 2. Effect of leptin on IL-6 and IL-8 production PDL cells and gingival fibroblasts. PDL cells and gingival fibroblasts (GF) were cultured for $24 \mathrm{~h}$ in the presence of either media alone or the indicated concentrations of leptin. Levels of IL-6 (A) and IL-8 (B) in culture supernatants were assayed ELISA. *Significant difference $(\mathrm{p}<0.05)$ compared to untreated cells.

PDL cells and gingival fibroblasts were treated with leptin in the presence of polymyxin B $(100 \mu \mathrm{g} / \mathrm{ml})$, an inhibitor of LPS. LPS increased IL-6 and IL-8 expression in both cell types (Fig. 3B and 3C left panel). Polymyxin B inhibited LPSinduced IL-6 and IL-8 expression (Fig. 3B and 3C left panel), but did not inhibit leptin-induced IL-6 and IL-8 expression in PDL cells and gingival fibroblasts (Fig. 3B and 3C right panel). The results of MTT assay in both cell types demonstrated that polymyxin B did not exert inhibitory effects on cell viability up to $500 \mu \mathrm{g} / \mathrm{ml}$ (Fig. 3A).

\section{Effect of leptin on LPS-induced IL-6 and IL-8 expression}

To observe the effect of leptin on IL-6 and IL-8 expression induced by LPS, PDL cells were treated with leptin in the presence of suboptimal dose of LPS and then the levels of cytokines in culture supernatants were estimated by ELISA. When PDL cells were treated with 2 and $5 \mathrm{ng} / \mathrm{ml}$ LPS, IL-6 and IL-8 expression increased in a dose-dependent manner (Fig. 4). When the PDL cells were treated with leptin in the presence or absence of $2 \mathrm{ng} / \mathrm{ml}$ LPS, LPS and leptin combination treated cells showed an increase tendency of IL- 6 and IL-8 expression compared to LPS-treated cells, but it was not significant. 
A.

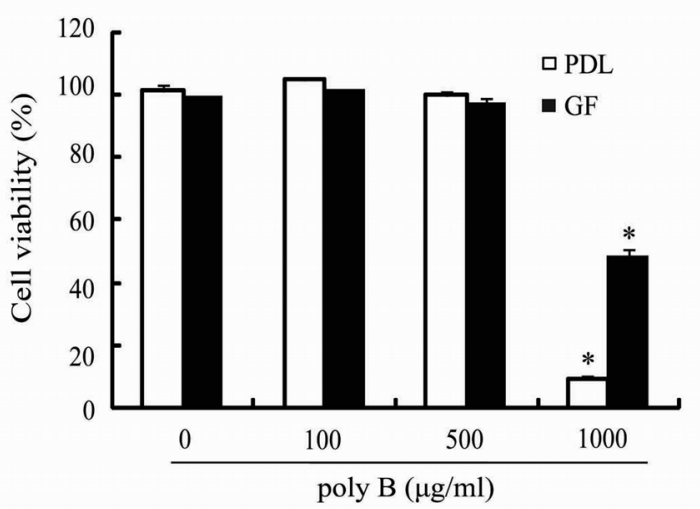

B.
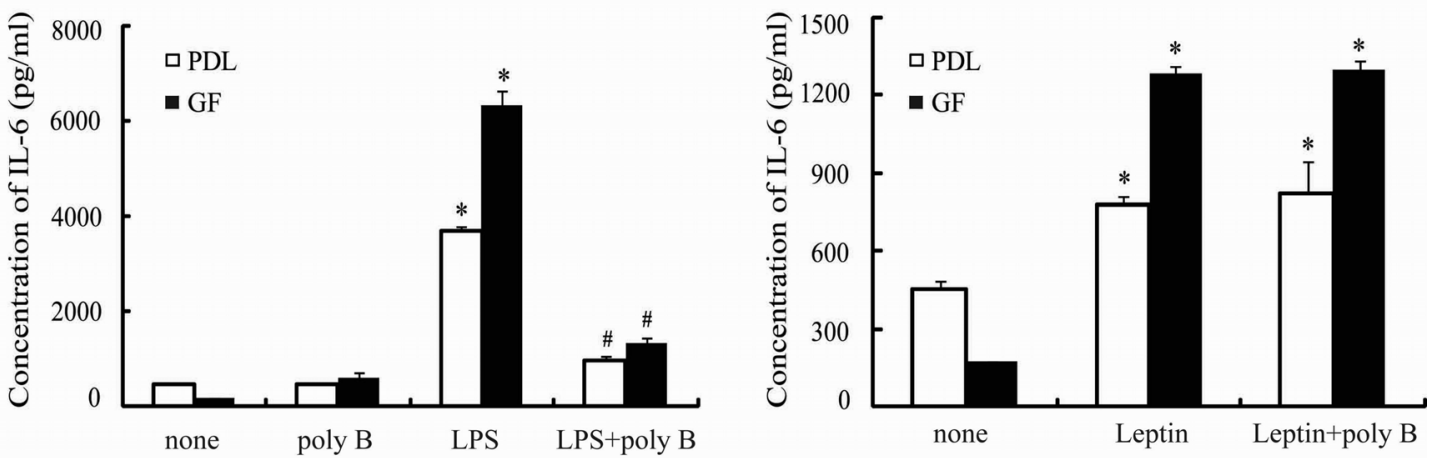

C.
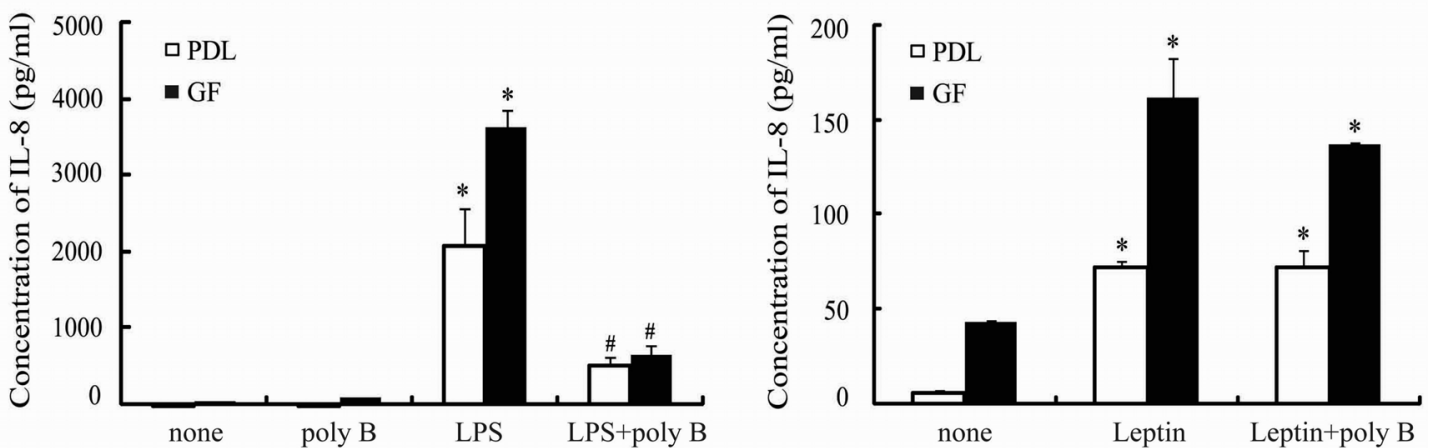

Fig. 3. Effect of polymyxin B (poly B) on leptin-induced cytokine expression of PDL cells and gingival fibroblasts. PDL cells and gingival fibroblasts (GF) were treated with poly B for $24 \mathrm{~h}$ and cell viability was estimated by the MTT assay (A). Cells were cultured for $24 \mathrm{~h}$ in the presence of either media alone, leptin $(10 \mu \mathrm{g} / \mathrm{ml})$, or LPS $(100 \mathrm{ng} / \mathrm{ml})$ in the presence or absence of poly B $(100 \mu \mathrm{g} / \mathrm{ml})$. Levels of IL-6 (B) and IL-8 (C) in culture supernatants were assayed by ELISA. *Significant difference (p<0.05) compared to untreated cells. \# Significant difference $(p<0.05)$ compared to LPS-treated cells.

\section{Expression of phosphorylated Akt and Erk1/2}

Phosphorylation of Akt and Erk1/2 was estimated in leptintreated PDL cells by western blot. As shown in Fig. 5, Akt phosphorylation increased at 15 min after leptin treatment, but it decreased gradually at 30 and $60 \mathrm{~min}$. The Erk1/2 phosphorylation expression pattern was similar to that of Akt.

\section{Discussion}

Leptin is mainly produced from adipocytes [18] and in minor quantities in placenta [19], gastric mucosa [20], T cells [21], and osteoblasts [22]. In addition, dermal fibro 


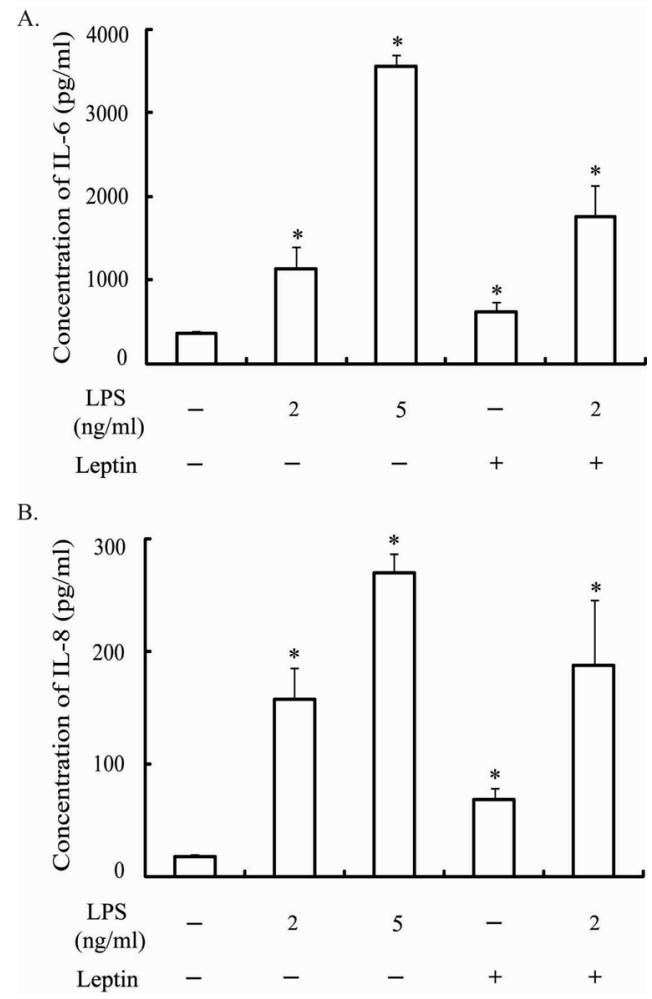

Fig. 4. Effect of leptin on LPS-induced cytokine expression of PDL cells. PDL cells were cultured for $24 \mathrm{~h}$ in the presence of leptin $(10 \mu \mathrm{g} / \mathrm{ml})$ or/and LPS (2 and $5 \mathrm{ng} / \mathrm{ml})$ and levels of IL-6 (A) and IL-8 (B) in culture supernatants were assayed by ELISA. *Significant difference $(\mathrm{p}<0.05)$ compared to untreated cells.

blasts also express leptin and leptin receptors, suggesting that leptin produced from fibroblasts, may exert local autocrine and paracrine actions and contribute to the plasma levels of leptin [23]. PDL cells and gingival fibroblasts are repre- sentative cells in periodontal tissues. Therefore, we examined whether leptin and leptin receptors are expressed in PDL cells and gingival fibroblasts. Adipose tissue expressed leptin mRNA, but PDL cells and gingival fibroblasts did not express leptin mRNA. This indicates that PDL cells and gingival fibroblasts are not a source of leptin in periodontal tissue. PDL cells and gingival fibroblasts expressed the long and short forms of the leptin receptor similar to expression in THP-1 macrophages which express both the long and short forms of the leptin receptor [24]. Among the leptin receptors of gingival fibroblasts, expression of the short form 219.2 was weaker than that of other short forms. This pattern is similar to dermal fibroblasts and adrenal tissue $[16,23]$. Among the leptin receptors, long form is known to transduce the activation signal $[1,4]$. Taken together, it is considered that leptin may affect the function of PDL cells and gingival fibroblasts via long form of leptin receptor.

Leptin acts as a stimulator of cytokines such as IL-1, IL-6, IL-8, and TNF in various cells including monocytes, macrophages, and synovial fibroblasts $[1,11,24,25]$. In this study, leptin increased IL-6 and IL-8 expression in PDL cells and gingival fibroblasts. Because leptin used in this study was are recombinant protein, we treated PDL cell and gingival fibroblasts with leptin in the presence of polymyxin $\mathrm{B}$, an inhibitor of LPS to rule out the activity of contaminated LPS. Polymyxin B inhibited LPS-induced IL-6 and IL-8 expression, but did not block the IL-6 and IL-8 expression induced by leptin in both cells. These results indicate that leptin acts as an inducer of IL-6 and IL-8 in
A.

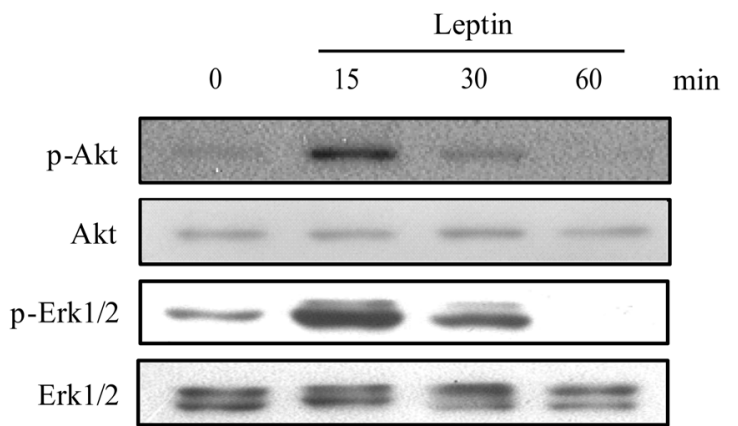

B.

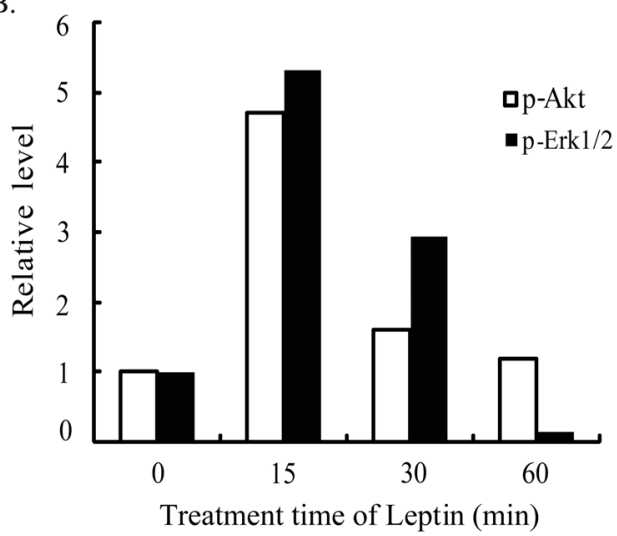

Fig. 5. Phosphorylation of Akt and Erk1/2 in leptin-treated PDL cells. PDL cells were cultured in the absence or presence of leptin $(10 \mu \mathrm{g} / \mathrm{ml})$ for the indicated times. Cell lysates were subjected to immunoblot analysis with antibodies recognizing the phosphorylated Akt or Erk1/2 and with antibody recognizing total Akt or Erk1/2 as loading controls (A). The phosphorylation value at 0 min was set to 1 to allow comparison with the relative phosphorylation levels at subsequent time-points (B). 
PDL cells and gingival fibroblasts. In other study using PDL cells and gingival fibroblasts from same donor, concentration of LPS which began to increase IL-6 expression was different between PDL cells and gingival fibroblasts, suggesting that PDL cells and gingival fibroblasts have a different ability to produce IL-6 [26]. Similar to the response to LPS, concentration of leptin which increased the expression of cytokines was different between PDL cells and gingival fibroblasts. However, we did not compare response of PDL cells and gingival fibroblasts cultured from same donor. Therefore, it will be needed to confirm the different response of both cells from same donor.

In macrophages, leptin treatment not only induced TNF and IL-8 production, but also enhanced LPS-induced TNF production. However it did not alter LPS-induced IL-8 production [24]. Most representative periodontopathogens are gram negative bacteria containing LPS. Therefore, we also observed the effect of leptin on cytokine expression induced by suboptimal dose of LPS in PDL cells. LPS increased the expression of IL-6 and IL-8 in PDL cells, but leptin did not change the expression of these cytokines induced by LPS. This indicates that leptin cannot potentiate LPS-induced IL-6 and IL-8 expression in both cells.

The leptin-signaling pathways are closely related with STAT signaling pathway, MAPK signaling pathway, and Erk signaling pathway [3]. In this study, leptin-treated PDL cells showed increased activation of Akt and Erk1/2 as eosinophils, synovial fibroblasts, and adipose tissue activated by leptin $[11,27,28]$. These results suggest that Akt and Erk1/2 may be involved in IL-6 and IL-8 expression.

Patients with rheumatoid arthritis display increased circulating leptin levels in comparison with a healthy group [29]. Leptin expression in cartilage of patients with osteoarthritis is higher than that in a normal group [30]. Leptin increases IL-8 production in synovial fibroblasts cultured from patients with rheumatoid arthritis and osteoarthritis [11]. These studies suggest that leptin plays an important role in inflammation such as rheumatoid arthritis and osteoarthritis. We found that leptin acts as pro-inflammatory cytokine in periodontal tissue through induction of IL-6 and IL-8 in PDL cells and gingival fibroblasts. In contrast to the leptin level in cartilage tissue of patients with osteoarthritis, the leptin level in GC and gingival tissues in patients with periodontitis is lower than that in a healthy group [7-9,31]. In the future, in vivo study will be necessary to determine whether the pro-inflammatory effect of leptin is beneficial or detrimental to periodontal tissue.

In this study, we first showed that leptin receptors are expressed in PDL cells and gingival fibroblasts and that leptin acts as an inducer of IL- 6 and IL-8 in both cell types. These results suggest that leptin affects induction of proinflammatory cytokines in periodontal tissue.

\section{Acknowledgements}

This study was supported by a grant of the Korean Health Technology R\&D Project, Ministry of Health \& Welfare, Republic of Korea (A101630). This research was supported by Basic Science Research Program through the National Research Foundation of Korea (NRF) funded by the Ministry of Education, Science and Technology (NRF-2009-0073136)

\section{Conflicts of interest}

We have no conflicts of interest relevant to this article.

\section{References}

1. Carbone F, La Rocca C, Matarese G. Immunological functions of leptin and adiponectin. Biochimie. 2012;94:2082-2088.

2. Lago F, Dieguez C, Gomez-Reino J, Gualillo O. Adipokines as emerging mediators of immune response and inflammation. Nat Clin Pract Rheumatol. 2007;3:716-724.

3. Lam QL, Lu L. Role of leptin in immunity. Cell Mol Immunol. 2007;4:1-13.

4. Gan L, Guo K, Cremona ML, McGraw TE, Leibel RL, Zhang Y. TNF-alpha up-regulates protein level and cell surface expression of the leptin receptor by stimulating its export via a PKC-dependent mechanism. Endocrinology. 2012;153:5821-5833.

5. Jun HK, Lee LS, Lee HR, Choi BK. Binding of Tp92 homolog of Treponema denticola to fibronectin and epithelial cells. Int J Oral Biol. 2008;33:45-50.

6. Choi EK, Kang IC. Production of pro-inflammatory cytokines by Porphyromonas gingivalis in THP-1 macrophagic cells. Int J Oral Biol. 2009;34:87-95.

7. Karthikeyan BV, Pradeep AR. Leptin levels in gingival crevicular fluid in periodontal health and disease. J Periodontal Res. 2007;42:300-304.

8. Karthikeyan BV, Pradeep AR. Gingival crevicular fluid and serum leptin: their relationship to periodontal health 
and disease. J Clin Periodontol. 2007;34:467-472.

9. Bozkurt FY, Yetkin Ay Z, Sutcu R, Delibas N, Demirel R. Gingival crevicular fluid leptin levels in periodontitis patients with long-term and heavy smoking. J Periodontol. 2006;77:634-640.

10. Gundala R, Vk C, K R. Association of leptin in periodontitis and acute myocardial infarction. J Periodontol. 2012.

11. Tong KM, Shieh DC, Chen CP, Tzeng CY, Wang SP, Huang KC, Chiu YC, Fong YC, Tang CH. Leptin induces IL-8 expression via leptin receptor, IRS-1, PI3K, Akt cascade and promotion of NF- $\kappa \mathrm{B} / \mathrm{p} 300$ binding in human synovial fibroblasts. Cell Signal. 2008;20:1478-1488.

12. Ezure T, Amano S. Adiponectin and leptin up-regulate extracellular matrix production by dermal fibroblasts. Biofactors. 2007;31:229-236.

13. Scheres N, Laine ML, de Vries TJ, Everts V, van Winkelhoff AJ. Gingival and periodontal ligament fibroblasts differ in their inflammatory response to viable Porphyromonas gingivalis. J Periodontal Res. 2010;45:262-270.

14. Scheller J, Chalaris A, Schmidt-Arras D, Rose-John S. The pro- and anti-inflammatory properties of the cytokine interleukin-6. Biochim Biophys Acta. 2011;1813:878-888.

15. Baggiolini M, Walz A, Kunkel SL. Neutrophil-activating peptide-1/interleukin 8 , a novel cytokine that activates neutrophils. J Clin Invest. 1989;84:1045-1049.

16. Glasow A, Haidan A, Hilbers U, Breidert M, Gillespie J, Scherbaum WA, Chrousos GP, Bornstein SR. Expression of $\mathrm{Ob}$ receptor in normal human adrenals: differential regulation of adrenocortical and adrenomedullary function by leptin. J Clin Endocrinol Metab. 1998;83:4459-4466.

17. Ramis JM, Bibiloni B, Moreiro J, Garcia-Sanz JM, Salinas R, Proenza AM, Llado I. Tissue leptin and plasma insulin are associated with lipoprotein lipase activity in severely obese patients. J Nutr Biochem. 2005;16:279-285.

18. Maffei M, Fei H, Lee GH, Dani C, Leroy P, Zhang Y, Proenca R, Negrel R, Ailhaud G, Friedman JM. Increased expression in adipocytes of ob RNA in mice with lesions of the hypothalamus and with mutations at the $d b$ locus. Proc Natl Acad Sci U S A. 1995;92:6957-6960.

19. Masuzaki H, Ogawa Y, Sagawa N, Hosoda K, Matsumoto T, Mise H, Nishimura H, Yoshimasa Y, Tanaka I, Mori T, Nakao K. Nonadipose tissue production of leptin: leptin as a novel placenta-derived hormone in humans. Nat Med. 1997;3:1029-1033.

20. Bado A, Levasseur S, Attoub S, Kermorgant S, Laigneau JP, Bortoluzzi MN, Moizo L, Lehy T, Guerre-Millo M, Le Marchand-Brustel Y, Lewin MJ. The stomach is a source of leptin. Nature. 1998;394:790-793.
21. Sanna V, Di Giacomo A, La Cava A, Lechler RI, Fontana S, Zappacosta S, Matarese G. Leptin surge precedes onset of autoimmune encephalomyelitis and correlates with development of pathogenic T cell responses. J Clin Invest. 2003; 111:241-250.

22. Reseland JE, Syversen U, Bakke I, Qvigstad G, Eide LG, Hjertner O, Gordeladze JO, Drevon CA. Leptin is expressed in and secreted from primary cultures of human osteoblasts and promotes bone mineralization. J Bone Miner Res. 2001;16:1426-1433.

23. Glasow A, Kiess W, Anderegg U, Berthold A, Bottner A, Kratzsch J. Expression of leptin $(\mathrm{Ob})$ and leptin receptor $(\mathrm{Ob}-\mathrm{R})$ in human fibroblasts: regulation of leptin secretion by insulin. J Clin Endocrinol Metab. 2001;86:4472-4479.

24. Kim SJ. Leptin potentiates Prevotella intermedia lipopolysaccharide-induced production of TNF- $a$ in monocyte-derived macrophages. J Periodontal Implant Sci. 2010;40:119-124.

25. Santos-Alvarez J, Goberna R, Sanchez-Margalet V. Human leptin stimulates proliferation and activation of human circulating monocytes. Cell Immunol. 1999;194:6-11.

26. Morandini AC, Sipert CR, Gasparoto TH, Greghi SL, Passanezi E, Rezende ML, Sant'ana AP, Campanelli AP, Garlet GP, Santos CF. Differential production of macrophage inflammatory protein-1a, stromal-derived factor-1, and IL- 6 by human cultured periodontal ligament and gingival fibroblasts challenged with lipopolysaccharide from P. gingivalis. J Periodontol. 2010;81:310-317.

27. Lappas M, Permezel M, Rice GE. Leptin and adiponectin stimulate the release of proinflammatory cytokines and prostaglandins from human placenta and maternal adipose tissue via nuclear factor- $\kappa \mathrm{B}$, peroxisomal proliferatoractivated receptor- $\gamma$ and extracellularly regulated kinase 1/2. Endocrinology. 2005;146:3334-3342.

28. Wong CK, Cheung PF, Lam CW. Leptin-mediated cytokine release and migration of eosinophils: implications for immunopathophysiology of allergic inflammation. Eur J Immunol. 2007;37:2337-2348.

29. Otero M, Lago R, Gomez R, Lago F, Dieguez C, GomezReino JJ, Gualillo O. Changes in plasma levels of fatderived hormones adiponectin, leptin, resistin and visfatin in patients with rheumatoid arthritis. Ann Rheum Dis. 2006;65:1198-1201.

30. Dumond H, Presle N, Terlain B, Mainard D, Loeuille D, Netter P, Pottie P. Evidence for a key role of leptin in osteoarthritis. Arthritis Rheum. 2003;48:3118-3129.

31. Johnson RB, Serio FG. Leptin within healthy and diseased human gingiva. J Periodontol. 2001;72:1254-1257. 